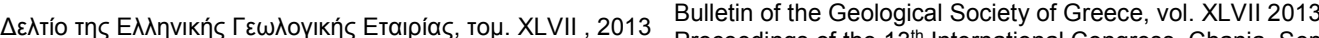
Proceedings of the $13^{\text {th }}$ International Congress, Chania, Sept.

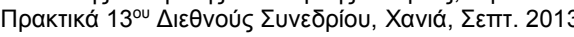
2013

\title{
THE PROSPECT OF USING GREEK LIGNITE IN AN ENERGY PORTFOLIO RELATED TO POWER GENERATION
}

\author{
Papanicolaou C. ${ }^{1}$, Typou J. ${ }^{2}$, Ioakeim $\mathrm{J.}^{2}$, Kotis Th. ${ }^{1}$ and Foscolos A. ${ }^{3}$ \\ ${ }^{1}$ Institute of Geology \& Mineral Exploration, 1st Spirou Louis St., Olympic Vilage, Acharnae, \\ P.C.13677,Athens, cassipapani@igme.gr,thkotis@gmail.com \\ ${ }^{2}$ Public Power Corporation SA/West Macedonia Lignite Center, \\ i.typou@dei.com.gr,i.ioakeim@dei.com.gr \\ ${ }^{3}$ Technical University of Crete / Department of Mineral Resources Engineering, Chania, Crete, \\ foscolos@mred.tuc.gr
}

\begin{abstract}
The lignite-based power generation contributes $38 \%$ towards Greece's energy independence. Reducing the lignite use while simultaneously importing more expensive natural gas both government deficit and the cost of energy will increase. This surcharge is passed to consumers. Switching to renewable resources invokes an even greater fiscal imbalance, since the costs from the use of wind turbines and solar photovoltaic panels are $87 € / M W h$, and 180-284 $€ / M W h$ respectively, while natural gas stands at $95 € / M W h$ and lignite-derived energy is $45 € / M W h$.

In case of replacing a $300 \mathrm{MW}$ lignite fed power unit with a $300 \mathrm{MW}$ natural gas fed power unit, the loss in income will be 66,540,000 €/year. Coupled with the increased cost of natural gas $(31,800,000 €$ lyear) the total is 98,340,000 $€ /$ year in addition to the loss of 1235 jobs.

Greek authorities intends to replace lignite-fired plants having a total installed capacity of $2531 \mathrm{MW}$ with equivalent natural gas-fired plants resulting in annual total deficit in excess of $787 \mathrm{M} \epsilon$. The targets set by the Greek Ministry of Energy and Climatic Changes to reduce emissions include halving Greek lignite-derived power output from $4800 \mathrm{MW}$ to $2300 \mathrm{MW}(>-52 \%)$. This move simultaneously increases Greek energy dependence on expensive foreign energy sources and will potentially provoke social unrest at the loss of 12500 jobs with loss of annual income on the order of $670 \mathrm{M \epsilon}$. However, if the existing power output from lignite-fed power plants is maintained, the penalty that PPC (Public Power Corporation) has to pay for the resultant $\mathrm{CO}_{2}$ emissions is significantly smaller $(300 \mathrm{M} €$ at $7.5 € / t$ of emitted $\mathrm{CO}_{2} / G W h$.

Proceeding with the immediate reduction in lignite-fired energy results in economic and social catastrophe (annual income loss:-670 million $€+$ annual $\mathrm{CO}_{2}$ emissions penalty: $348 \mathrm{M} \epsilon=-322 \mathrm{M \epsilon}$ ). Lignite-fired plants will become obsolete only when the $\mathrm{CO}_{2}$ emissions penalty exceeds $63.5 \mathrm{\epsilon} / \mathrm{t}$ of emitted $\mathrm{CO}_{2} / \mathrm{GWh}$ from a purely economic perspective.
\end{abstract}

Key words: Power units, $\mathrm{CO}_{2}$, Natural gas. 


\section{Пєрí $\eta \psi \eta$}

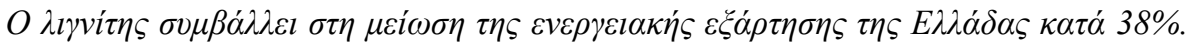

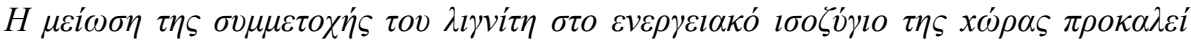

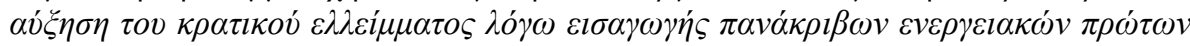

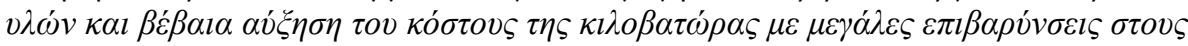

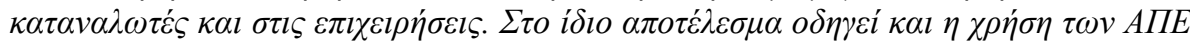

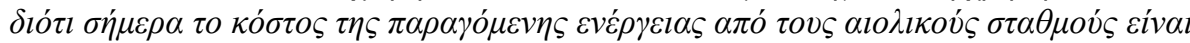

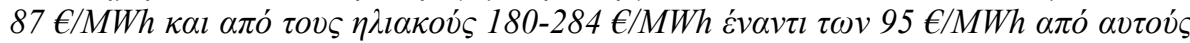

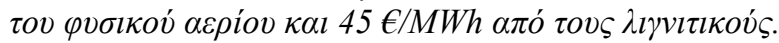

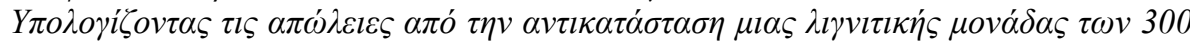

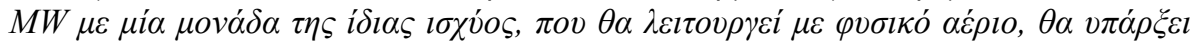

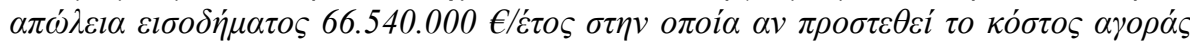

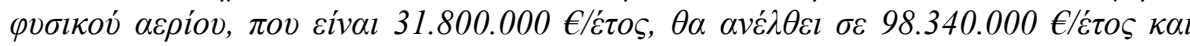

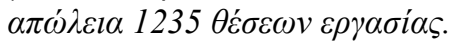

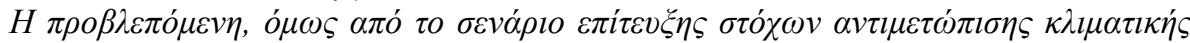

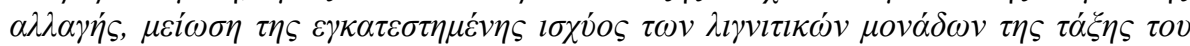

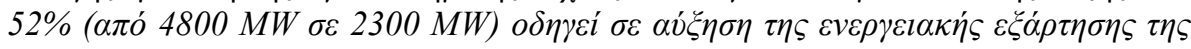

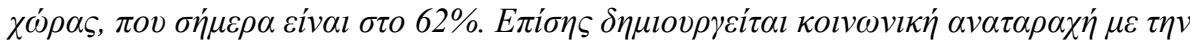

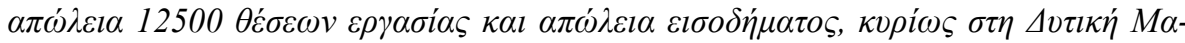
$\kappa \varepsilon \delta o v i ́ \alpha, \tau \eta \varsigma \tau \dot{\alpha} \xi \eta \varsigma \tau \omega v 670 \mathrm{M \epsilon} / \dot{\varepsilon} \tau o \varsigma$.

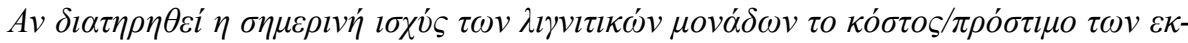

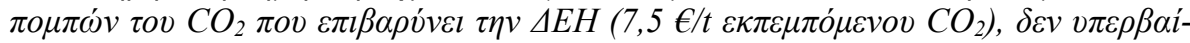

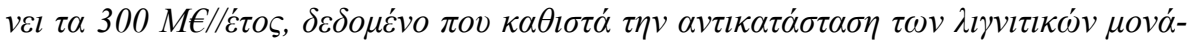

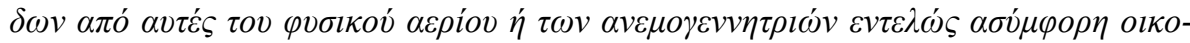

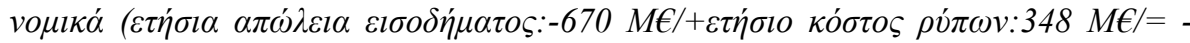

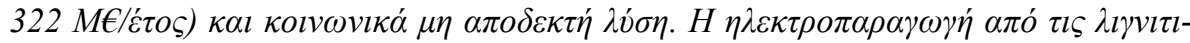

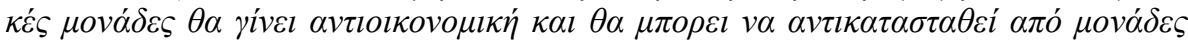

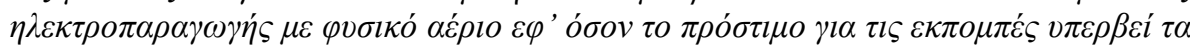

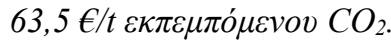

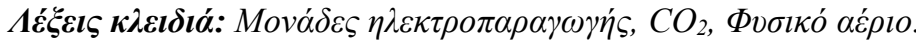

\section{Introduction}

The use of lignite for power generation in Greecebegan in 1953 following the construction of the $125 \mathrm{MW}$ power plants at Aliveri, Evia. To day there are 19 power units throughout Greece with a total installed capacity of $4826 \mathrm{MW}$. These units are fed with $58 \mathrm{Mt}$ of lignite/year from the surrounding coal mines. The Lignite Center of Western Macedonia in Greece directly employs 7780 workers, while each job creates a further 3.28 (Technical Chamber of Greece, 2012) indirect jobs in the region for a total of 25,518 jobs.

Lignite contributes 38\% to Greece's energy independence (Figure 1). Decreasing its relative importance in the energy portfolio will increase the budget deficit due to reliance on imported energy raw materials which will increase the cost of generated $\mathrm{kWh}$.

Lignite feedstock represents the cheapest cost per MWh (45€), followed by wind turbines (87 $€ / \mathrm{MWh}$ ), natural gas (95 €/MWh) and solar photovoltaic (180-284 €/MWh) (Operator of Electricity Market, 2012; Regulatory Authority for Energy, 2012). Currently, renewable resources remain a very expensive option.

Greece's lignite reserves are presented in Table 1 while the distribution of the mineable ones is shown in Figure 2.

$\underline{\text { XLVII, No } 3-2122}$ 


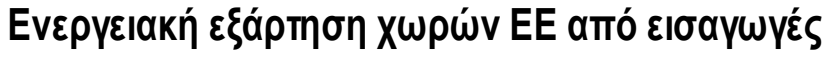

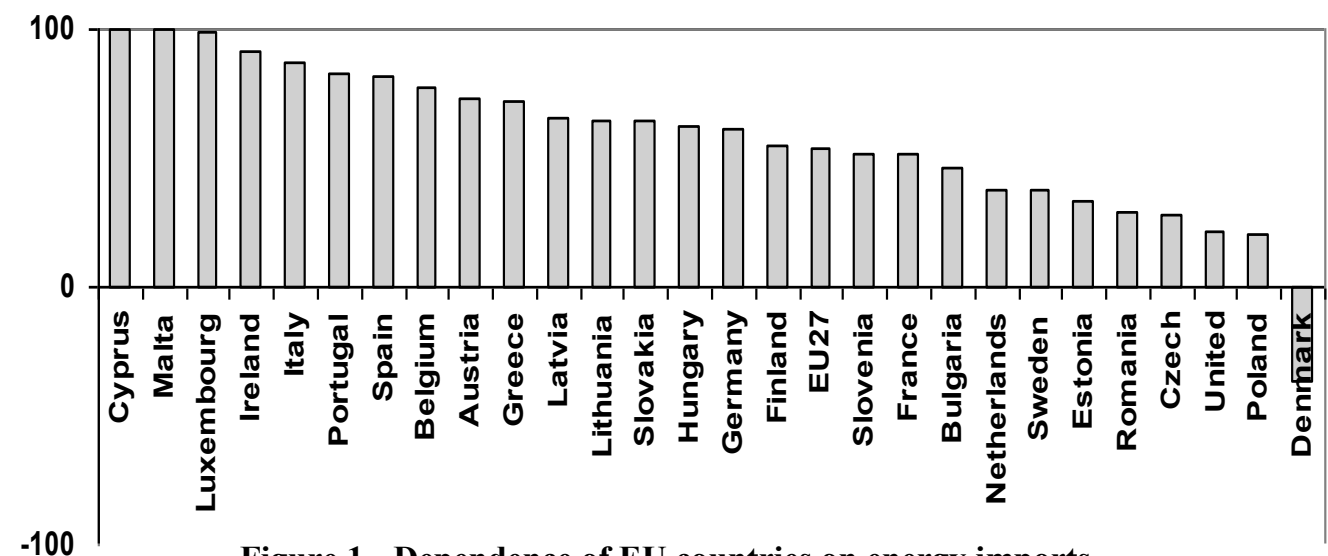

Figure 1 - Dependence of $E U$ countries on energy imports.

Table 1 - Ligniterresgebyesentumenillion tonnes.

\begin{tabular}{|l|c|c|}
\hline A. & PROVEN & 9300 \\
\hline & $\bullet$ MINEABLE & 3320 \\
\hline & $\bullet$ NON MINEABLE & 2850 \\
\hline & $\bullet \quad$ PHILIPPI PEAT & $1700^{(1)}$ \\
\hline & CONSUMED SINCE 1953 & 1350 \\
\hline B. & INDICATED & 1600 \\
\hline C. & INFERRED & 2300 \\
\hline
\end{tabular}

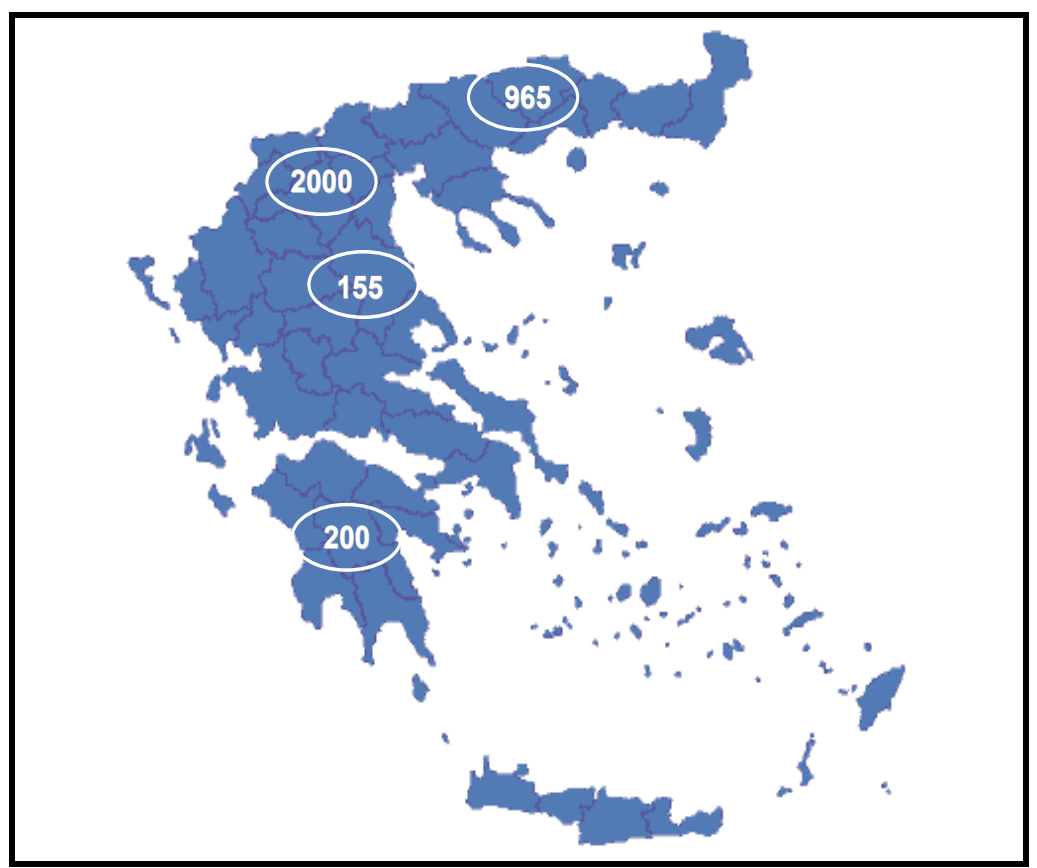

Figure 2 - The lignite deposits throughout Greece (in Mt) throughout Greece (Papanicolaou, 2001).

(1) $4300 \mathrm{Mt}$ of peat having, equivalent calorific value to Ptolemais lignites, $1350 \mathrm{kcal} / \mathrm{kg}$ 
Annual lignite production from the Lignite Center of Western Macedonia (LCWM) and the Lignite Center of Megalopolis, Peloponnese (LCMP) as well as their contribution to power generation in TWh are given in Tables 2 and 3.

The contribution of domestic lignite to the national economy should not be underestimated. Since 1960 a single area (Western Macedonia) has produced the energy equivalent of 1.15 billion barrels of oil, generating 562,000 GWh thus contributing $\$ 49.7$ billion (inflation-adjusted) to the Greek economy. It is considered that further exploitation of the remaining lignite reserves until 2054 will add to the economy $\$ 26$ billion not including the lignite reserves of Drama Basin (Philippi peatland) and those encountered in Elassona, Thessaly.

Table 2 - Lignite production (in kt) from the Lignite Center of Western Macedonia (LCWM) and the Lignite Center of Megalopolis, Peloponnese (LCMP) from 2006 to 2011 (Public Power Corporation of Greece S.A., 2011).

\begin{tabular}{|l|c|c|c|c|c|c|c|}
\hline & $\mathbf{2 0 0 6}$ & $\mathbf{2 0 0 7}$ & $\mathbf{2 0 0 8}$ & $\mathbf{2 0 0 9}$ & $\mathbf{2 0 1 0}$ & $\mathbf{2 0 1 1}$ & $\mathbf{2 0 1 2}$ \\
\hline LCWM & 49,000 & 49,300 & 40,250 & 50,300 & 43,200 & 47,400 & 52,100 \\
\hline LCMP & 13,500 & 14,100 & 13,200 & 11,500 & 10,400 & 9,350 & 9,600 \\
\hline TOTAL & $\mathbf{6 2 , 5 0 0}$ & $\mathbf{6 3 , 4 0 0}$ & $\mathbf{5 3 , 4 5 0}$ & $\mathbf{6 1 , 8 0 0}$ & $\mathbf{5 3 , 6 0 0}$ & $\mathbf{5 6 , 7 5 0}$ & $\mathbf{6 1 , 7 0 0}$ \\
\hline
\end{tabular}

Table 3 - Electricity generation (in TWh) and percent contribution of each source to the energy grid in Greece (European Union, 2012).

\begin{tabular}{|l|c|c|r|r|r|r|r|r|r|}
\hline Type/year & Units & $\mathbf{2 0 0 4}$ & $\mathbf{2 0 0 5}$ & $\mathbf{2 0 0 6}$ & $\mathbf{2 0 0 7}$ & $\mathbf{2 0 0 8}$ & $\mathbf{2 0 0 9}$ & $\mathbf{2 0 1 0}$ & $\mathbf{2 0 1 1}$ \\
\hline \multirow{2}{*}{ Lignite } & TWh & 35.38 & 35.54 & 32.26 & 34.68 & 33.36 & 34.19 & 30.8 & 27.57 \\
\cline { 2 - 10 } & $\%$ & 59.6 & 59.2 & 53.1 & 54.6 & 52.35 & 55.7 & 53.66 & 49.5 \\
\hline \multirow{2}{*}{ Natural Gas } & TWh & 9 & 8.2 & 10.61 & 13.77 & 13.8 & 11.02 & 9.8 & 14.85 \\
\cline { 2 - 10 } & $\%$ & 15.20 & 13.60 & 17.45 & 21.70 & 21.65 & 18.00 & 17.07 & 26.70 \\
\hline \multirow{2}{*}{ Oil } & TWh & 8.4 & 9.2 & 9.6 & 9.6 & 10 & 7.7 & 6.1 & 4.77 \\
\cline { 2 - 10 } & $\%$ & 14.10 & 15.30 & 15.79 & 15.20 & 15.70 & 12.50 & 10.60 & 8.60 \\
\hline \multirow{2}{*}{ Hydro } & TWh & 5.2 & 5.6 & 6.48 & 3.4 & 4.15 & 5.65 & 7.5 & 3.68 \\
\cline { 2 - 10 } & $\%$ & 8.80 & 9.40 & 10.66 & 5.30 & 6.50 & 9.20 & 13.07 & 6.60 \\
\hline \multirow{2}{*}{ Renewable } & TWh & 1.4 & 1.5 & 1.84 & 2.03 & 2.45 & 2.8 & 3.2 & 4.79 \\
\cline { 2 - 10 } & $\%$ & 2.30 & 2.50 & 3.00 & 3.20 & 3.80 & 4.60 & 5.60 & 8.60 \\
\hline \multirow{2}{*}{ TOTAL } & $\mathbf{T W h}$ & $\mathbf{5 9 . 4}$ & $\mathbf{6 0}$ & $\mathbf{6 0 . 8}$ & $\mathbf{6 3 . 5}$ & $\mathbf{6 3 . 7}$ & $\mathbf{6 1 . 4}$ & $\mathbf{5 7 . 4}$ & $\mathbf{5 5 . 6 6}$ \\
\cline { 2 - 9 } & $\mathbf{9}$ & $\mathbf{1 0 0}$ & $\mathbf{1 0 0}$ & $\mathbf{1 0 0}$ & $\mathbf{1 0 0}$ & $\mathbf{1 0 0}$ & $\mathbf{1 0 0}$ & $\mathbf{1 0 0}$ & $\mathbf{1 0 0}$ \\
\hline
\end{tabular}

\section{The Future of Greek Lignites in an Energy Portfolio Related to Power Generation as Perceived by the Scenario to Meet Climate Change}

\subsection{Financial and Social Impact}

The Greek government is currently attempting to respond to binding EU requirements to confront Climate Change. To this end, the Ministry of Environment, Energy and Climate Change Committee 20-20-20 on June 21, 2010 has proposed phased changes to the energy resource portfolio for the period until 2030 (Ministry of Environment, Energy and Climate Change, 2010). This initiative results from EU "Energy 2020" guidelines aimed at promoting competitive, viable and secure energy while at the same time reducing greenhouse gas emissions. The guidelines stipulate 
- $20 \%$ reduction in greenhouse gas emissions below 1990 levels

- $20 \%$ reduction of the energy needs to be produced from renewable energy sources

- $20 \%$ reduction in primary energy use to be achieved by improving energy efficiency

The measures should be implemented in such a way that economic and social impacts are minimized (Ministry of Environment, Energy and Climate Change, 2010). Hence, the scenario proposed by the Greek Committee from the Ministry of Environment, Energy and Climate Change (Table 4) shows the following shortcomings.

Table 4 - Scenario for meeting the $\mathrm{CO}_{2}$ emission targets set by the $\mathrm{EU}$ by 2030 (Ministry of Environment, Energy and Climate Change, 2010). Installed capacity in MW from various energy sources.

\begin{tabular}{|l|r|r|r|r|r|}
\hline \multicolumn{1}{|c|}{ ENERGY SOURCE } & $\mathbf{2 0 1 0}$ & $\mathbf{2 0 1 5}$ & $\mathbf{2 0 2 0}$ & $\mathbf{2 0 2 5}$ & $\mathbf{2 0 3 0}$ \\
\hline LIGNITE & 4,826 & 3,992 & 3,363 & 2,295 & 2,295 \\
\hline NATURAL GAS & 3,456 & 5,909 & 7,312 & 8,412 & 9,259 \\
\hline OIL & 2,146 & 1,381 & 1,378 & 1,378 & 1,325 \\
\hline BIOGAS & 60 & 120 & 250 & 370 & 500 \\
\hline HYDROELECTRIC & 3,237 & 3,615 & 4,531 & 4,531 & 4,531 \\
\hline WIND POWER & 1,327 & 4,303 & 7,500 & 8,750 & 10,000 \\
\hline PHOTOVOLTAIC & 184 & 1,270 & 2,200 & 3,167 & 3,833 \\
\hline GEOTHERMAL & 0 & 20 & 120 & 340 & 400 \\
\hline SOLAR COMB. SYSTEMS & 0 & 30 & 250 & 380 & 510 \\
\hline TOTAL & $\mathbf{1 5 , 2 3 6}$ & $\mathbf{2 0 , 6 4 0}$ & $\mathbf{2 6 , 9 0 3}$ & $\mathbf{2 9 , 6 2 3}$ & $\mathbf{3 2 , 6 5 3}$ \\
\hline
\end{tabular}

First, instead of implementing a reduction of energy consumption by $20 \%$ between the years 2010 to 2030 the proposal aims to double the installed power capacity from $15,236 \mathrm{MW}$ in 2010 to $32,653 \mathrm{MW}$ by 2030 . This is hard to justify in the face of far more modest increases in projected population growth and industrial output within the next 20 years. On the contrary, the last 3 years have seen the trend for increased energy demand reversed in the face of economic crisis, high unemployment, decrease in industrial output, and overseas migration of the working force. Doubling the installed power capacity is moreover contrary to EU directives for future energy management.

Secondly, the EU directive 20-20-20 proposes that from the total power capacity to be installed by 2030 over $59 \%$ (Table 4 ) should be derived from the renewable resources. About $30.6 \%$ will come from wind turbines, $12 \%$ from solar panels and the remaining $17.4 \%$ from hydro, geothermal and others. This not only renders the electrical grid unstable (Regulatory Authority for Energy, 2011) but also introduces energy sources which produce very expensive electricity. This high cost will be passed on to consumers

Third, using as an excuse the reduction of $\mathrm{CO}_{2}$ emissions in order to minimize the greenhouse effect, introduces overwhelmingly the consumption of imported natural gas, $28.4 \%$, at a delivery price of $16 \$ / G J$ or $12.31 € / G^{(2)}$ (National Natural Gas System Operator S.A., 2012) when the price of locally produced lignite is $3.5 \$ / G J$ or $2.7 € / G J$ (Kolovos, 2010) thus creating immense social and economic problems not only in western Greek Macedonia but in the whole country.

The EU guidelines did not specify what measures should be taken to reduce the $\mathrm{CO}_{2}$ emissions from the power plants but to reduce it in any way that Greek authorities considers appropriate. However in order to reduce $\mathrm{CO}_{2}$ emissions by 20\%, the so-called 20-20-20 Greek Committee has decided to reduce coal fired power by $50 \%$, creating a "vital space" for the introduction of very expensive energy sources thus neglecting the colossal social and economic impact without study-

(2) $1 €=1.30 \$$ 
ing alternative and less painful ways of achieving the directives set by EU. Specifically by substituting one $300 \mathrm{MW}$ coal fired power unit with an energy efficiency of $34 \%$ with an equivalent power unit which burns natural gas:

- Public Power Corporation S.A. of Greece (PPC) loses 31,820,000 € (annual cost of natural gas $93,170,000 €^{(3)}$ - annual cost of 4,090,000 t of lignite $\left.X 15 € / t=61,350,000 €\right)$ (Kolovos, 2010; National Natural Gas System Operator S.A, 2012; Technical Chamber of Greece, 2012).

- 1235 jobs are lost (each $300 \mathrm{MW}$ coal fired power unit creates 1559 jobs while each 300 MW power unit which uses natural gas creates 324 jobs) (Technical Chamber of Greece, 2012).

- An annual income of 66.54 M€ is lost (Loss of 1559 jobs leads to an annual income loss of $84 \mathrm{M} €$ (Technical Chamber of Greece, 2012) while the creation of 324 jobs from the equivalent natural gas power plant yields an annual income of 17.46 M€).

Consequently, the net loss is $66.54 \mathrm{M} € /$ year. Hence by decreasing the installed power of the coal fed power plants from $4828 \mathrm{MW}$, to $2295 \mathrm{MW}$ (Table 4), and counterbalancing this with power plants which are fed by natural gas (equivalent of eight 300MW coal fired power units) the net financial losses incurred by the Public Power Corporation S.A. of Greece will be 254,560,000 €. This is attributed to the price difference of the feedstock being $\$ 3.5 / \mathrm{GJ}$ or $2.7 € / \mathrm{GJ}$ for the indigenous lignite and $16 \$ / G J$ or $12.31 € / G J$, for the imported natural gas. On top of it, there is a net annual income loss of 532,320,000 € (loss of Income of $66.54 € /$ unit of $300 \mathrm{MW}$ unit X 8 units $=$ $532 \mathrm{M} €)$. This means a grand total annual loss of $787 \mathrm{M} €$.

If the new natural gas fed power plants are not going to be located in Greek Western Macedonia, 12500 jobs will be lost along with an annual income loss of $670 \mathrm{M} €$.

The Committee however goes one step further by proposing the power plants fed with natural gas to reach $9259 \mathrm{MW}$, which means that, besides the existing ones of $3456 \mathrm{MW}$ and the substitution of another $2531 \mathrm{MW}$ lignite fired power plants by natural gas, $3272 \mathrm{MW}$ natural gas fired power plants are going to be added. This means that besides the horrendous construction cost, Public Power Corporation S.A should pay for feeding the additional new $5803 \mathrm{MW}$ with natural gas the exuberant price of 1.8 billion $€\left(5803 \mathrm{MW} X 93,170,000 €^{(3)} / 300 \mathrm{MW}\right)$. One wonders from where the money will come for such an undertaking when Public Power Corporation S.A (PPC) tries to reduce its dependence from natural gas. PPC used 2,400,000 $\mathrm{kNm}^{3}, 1,700,000 \mathrm{kNm}^{3}$ and $1,000,000 \mathrm{kNm}^{3}$ of natural gas in 2007, 2009 and in 2011 respectively (Public Power Corporation, 2012). So the Greek Committee proposes the installation of more natural gas power plants that is complete dependence on the imported and very expensive natural gas.

Taking into account that the mean average $\mathrm{CO}_{2}$ emissions in the last 5 years from the lignite fired plants are $40 \mathrm{Mt}$ (mean price of the last five years) (United Nations Framework Convention on Climate Change, 2012) and that the penalty for it is $7.5 € / t$ of emitted $\mathrm{CO}_{2}$ (September 2012), the total annual sum to be paid by the Public Power Corporation S.A. for $\mathrm{CO}_{2}$ emissions, reaches 300 $\mathrm{M} €$ (The price of allowances is $3.5 € / \mathrm{t} \mathrm{CO}_{2}$ in March 2013). As a result, it is more preferable for Public Power Corporation S.A. of Greece to pay the annual penalty of $300 \mathrm{M} €$ for $\mathrm{CO}_{2}$ emissions than assume an annual loss of $787 \mathrm{M} €$. And pay the same amount of penalty than lose 12500 jobs in Western Greek Macedonia leading to an annual income loss of income of $670 \mathrm{M} €$.

\section{2. $\mathrm{CO}_{2}$ Emissions}

Based upon the guidelines of the European Committee 20-20-20 $\mathrm{CO}_{2}$ emissions from all power plants which are $46 \mathrm{Mt}$ (mean price of the last five years) (United Nations Framework Convention

(3) Each $300 \mathrm{MW}$ power unit using natural gas as feedstock and with an energy efficiency of $39 \%$ requires 7,568,640 GJ/year. Hence 7,568,640 GJ/year $\times € 12.31 / \mathrm{GJ}=93,170,000 €$ the cost of feedstock

$\underline{\text { XLVII, No } 3-2126}$ 
on Climate Change, 2012) should be reduced by $20 \%$ taking as a baseline the $\mathrm{CO}_{2}$ emissions in 1990 which were 40 million tonnes. This implies that by $2030 \mathrm{CO}_{2}$ emissions should not be more than $32 \mathrm{Mt}$.

By following the scenario which is presented in Table $4, \mathrm{CO}_{2}$ emissions instead of being reduced to $32 \mathrm{Mt}$ increase to $48.72 \mathrm{Mt}(14800 \mathrm{GWh}$ from the 2295 lignite fired power plants X $1100 \mathrm{t}$ of $\mathrm{CO}_{2} / \mathrm{GWh}=16.28 \mathrm{Mt}$ of $\mathrm{CO}_{2}$ (Figure 3). Plus, $64887 \mathrm{GWh}^{(4)}$ from the $9259 \mathrm{MW}$ natural gas power plants X $500 \mathrm{t}$ of $\mathrm{CO}_{2} / \mathrm{GWh}=32.443 \mathrm{Mt}$. So by following the scenario indicated in Table 4, instead of having reduction of the $\mathrm{CO}_{2}$ emissions an increase is got by $52 \%$ from the Directive's target. Furthermore, the operation of lignite fired power plants will become uneconomical when the penalty for $\mathrm{CO}_{2}$ emissions will reach the tag of $63.5 € / \mathrm{t}$ of emitted $\mathrm{CO}_{2}$ (Technical Chamber of Greece, 2012). Since this price may never be reached the guidelines set up by the Greek Committee 20-20-20 of the Ministry of Energy and Climatic Changes (Table 4) should be radically revised.

\subsection{Amount and Cost of Imported Natural Gas}

The amount of imported natural gas for the $9259 \mathrm{MW}$ power plants is huge. Each $300 \mathrm{MW}$ power plants need 7500000 GJ. Therefore the $9259 \mathrm{MW}$ power plants require $231,475 \mathrm{X} 10^{6} \mathrm{GJ}$. Since $1 \mathrm{GJ}$ is equal to 1000 cubic feet of natural gas then the amount of natural gas equals $231,475 \times 10^{9}$ $\mathrm{ft}^{3}$ or $6.55 \mathrm{Gm}^{3}$. Today Greece imports something in the order of $3.5 \mathrm{Gm}^{3}$. From where are we going to get the required amount of natural gas, $4.11 \mathrm{Gm}^{3}$, for the new $5803 \mathrm{MW}$ power plants $\left(145,075 \times 10^{6} \mathrm{GJ}=145,075 \times 10^{9}\right.$ cubic feet of natural gas $/ 35.315$ cubic feet of natural gas $/ \mathrm{m}^{3}=$ $4.11 \mathrm{Gm}^{3}$ of natural gas). The annual cost of importing $231,475 \times 10^{6} \mathrm{GJ}$ is calculated on the basis of $\$ 16 / \mathrm{GJ}$. This totals 3.7 billion $\$$ or 2.85 billion $€$. And the annual penalty for the $\mathrm{CO}_{2}$ emissions will increase from the to days $348 \mathrm{M} €\left(46,400,500 \mathrm{t}\right.$ of emitted $\mathrm{CO}_{2} \mathrm{X} 7.5 € / \mathrm{t}$ of emitted $\mathrm{CO}_{2} / \mathrm{GWh}$ $=348 \mathrm{M€})$ to $366 \mathrm{M€}$.

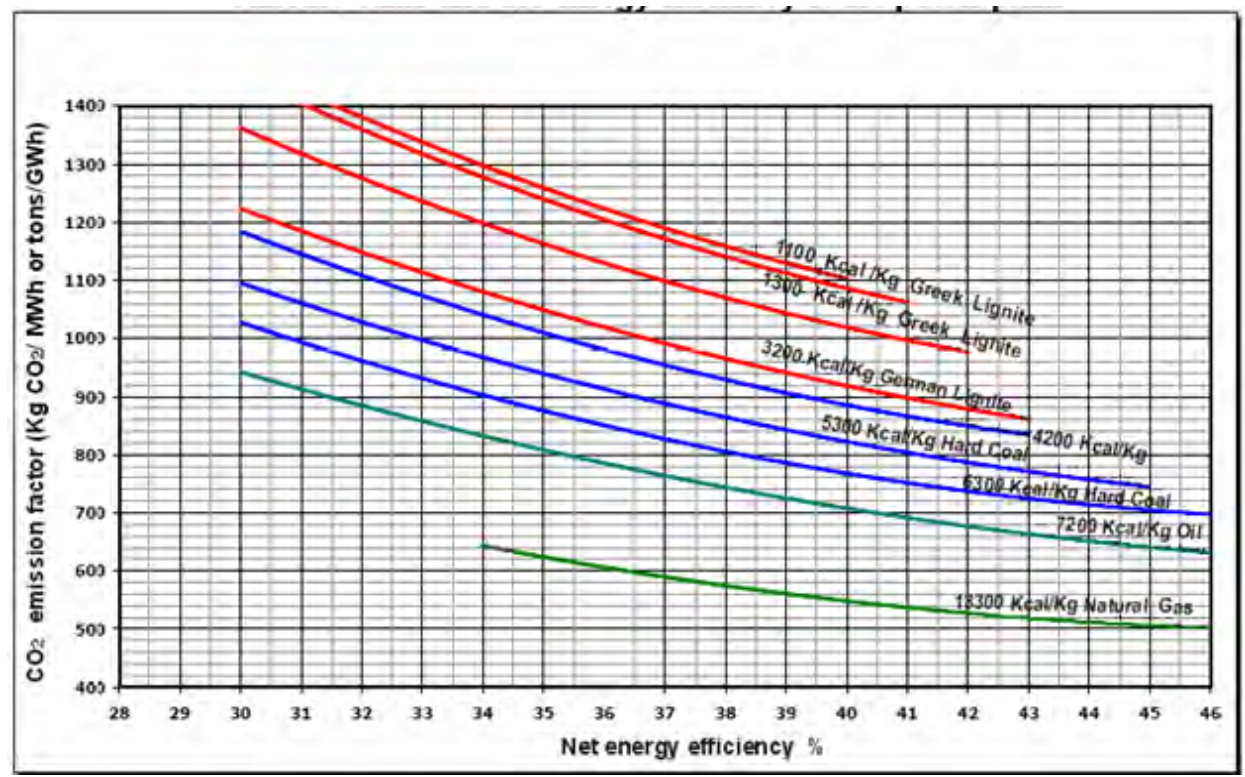

Figure 3 - Correlation of $\mathrm{CO}_{2}$ emissions ( $\mathrm{kg} \mathrm{CO}_{2} / \mathrm{MWh}$ or $\mathrm{t} / \mathrm{GWh}$ ) with the type of coal and hydrocarbon burnt its lower calorific value and the energy efficiency of the power plant (Technical Chamber of Greece, 2012).

(4) Each 300MW unit which is fed with natural gas and with an energy efficiency of $39 \%$ produces, annually, 2,102.4 GWh. Hence the $9259 \mathrm{MW}$ power stations will produce $9259 \mathrm{MW} \times 2,102.4 \mathrm{GWh} / 300 \mathrm{MW}=$ $64,887.072 \mathrm{GWh}$

XLVII, No $3-2127$ 
Hence, the efforts of the Greek government to respond to the binding requirements to confront the Climatic Changes, Ministry of Environment, Energy and Climate Change Committee 20-20-20 in June 21, 2010 by advancing the energy portfolio which appears on Table 4 should be radically revised otherwise we will be facing a social unrest, especially in Western Macedonia, Greece will totally lose its energy independence since the country will rely exclusively on imported energy sources, Public Power Corporation of Greece S.A. will go bankrupt, the power grid will become totally unstable due to the excessive introduction of wind turbines while the price of electricity will skyrocket.

In order to conform to the European 20-20-20 guidelines the following are proposed:

- Reduction of energy consumption from $60340 \mathrm{GWh}$ which is the mean average of the last 5 years (Table 3) to $48272 \mathrm{GWh}$.

- $55 \%$ of the $48272 \mathrm{GWh}$ will be derived from newly constructed lignite fed power plants having an energy efficiency of 40\%. The amount of CO2 emitted will be $29.21 \mathrm{Mt} / \mathrm{year}$ (26550 GWh X 1100 t CO2/GWh).

- $30 \%$ of the $48272 \mathrm{GWh}$, which is $14483 \mathrm{GWh}$ will be derived from renewable resources. Particularly, $15 \%$ will be the contribution from wind turbines having an installed power of $4000 \mathrm{MW}$ and $15 \%$ from the hydroelectric power with an installed capacity of $2600 \mathrm{MW}$ while $\mathrm{CO} 2$ emissions will be zero.

- $15 \%$ of the $48272 \mathrm{GWh}$ that is $7241 \mathrm{GWh}$ will be derived from natural gas power plants with an installed capacity of $3000 \mathrm{MW}$ and energy efficiency of $43 \%$ to $44 \%$ thus emitting 3.69 Mt of CO2/year (7241GWh X 510 t CO2/GWh).

\section{Conclusions}

In the present work a detailed study of the future energy portfolio, which is related to power generation as perceived by the Greek Committee 20-20-20, set up by the Ministry of Energy and Climatic Changes, for meeting the climatic changes, is examined in relation to the European 2020-20 guidelines which stipulates reduction of power consumption by $20 \%$, reduction of $\mathrm{CO}_{2}$ emissions from power plants by $20 \%$ and power production by renewable resources $20 \%$. Unfortunately the goals suggested by the European guidelines were not implemented and the necessity of revision is imperative. Specifically,

- It doubles, unjustifiably, the installed capacity for power generation from $15236 \mathrm{MW}$ to 32653 MW contrary to the EU recommendations which stipulates $20 \%$ reduction.

- Introduces into the power system more than $60 \%$ the renewable resources. Over $42 \%$ is the contribution from wind turbines and photovoltaic systems and the remaining $17.4 \%$ from hydro and geothermal that renders the electrical grid unstable and introduces energy sources for power generation which produce very expensive electricity, $>87 € / \mathrm{MWh}$ for wind turbines and $180 € / \mathrm{MWh}$ to $284 € / \mathrm{MWh}$ for solar panels versus $45 € / \mathrm{MWh}$ from lignites

- Presupposes the import of additional $4.11 \mathrm{Gm}^{3}$ of natural gas to feed the new $5803 \mathrm{MW}$ power plants at an annual cost of 2.32 billion $\$$ or 1.78 billion $€$. Today Greece imports 3.5 $\mathrm{Gm}^{3}$ of natural gas.

- Imposes on Public Power Corporation of Greece S.A. to buy expensive natural gas at a price of $16 \$ / G J(12.31 € / G J)$ thus spending annually 3.7 billion $\$$ or 2.85 billion $€$.

- Increases CO2 emissions to $48.72 \mathrm{Mt} /$ year instead of reducing it to $32 \mathrm{Mt}$ as required by the EU guidelines. Thus promoting a $52 \%$ increase of $\mathrm{CO} 2$ emissions.

- Promotes an annual income loss of $670 \mathrm{M} €$ derived from the laying off of 12500 jobs in western Greek Macedonia thus creating a social unrest something that the European guidelines do not stipulate.

XLVII, No $3-2128$ 
In order to conform to the European 20-20-20 guidelines the following are proposed:

- Reduction of energy consumption from $60340 \mathrm{GWh}$ which is the mean average of the last 5 years to $48272 \mathrm{GWh}$.

- $55 \%$ of the $48272 \mathrm{GWh}$ will be derived from newly constructed lignite fed power plants having an energy efficiency of $40 \%$. The amount of $\mathrm{CO} 2$ emitted will be $29.21 \mathrm{Mt} / \mathrm{year}$ (26550 GWh X 1100 t CO2/GWh.

- $30 \%$ of the $48272 \mathrm{GWh}$ that is $14483 \mathrm{GWh}$ will be derived from renewable resources. $15 \%$ will be the contribution from wind turbines having an installed power of $4000 \mathrm{MW}$ and $15 \%$ from the hydroelectric power with an installed capacity of $2600 \mathrm{MW}$. CO2 emissions will be zero.

- $15 \%$ of the $48272 \mathrm{GWh}$ that is $7241 \mathrm{GWh}$ will be derived from natural gas power plants with an installed capacity of $3000 \mathrm{MW}$ and energy efficiency of $43 \%$ to $44 \%$ thus emitting $3.69 \mathrm{Mt}$ of CO2/year (7241 GWh X 510 t CO2/GWh)

Thus following to a large extend the guidelines 20-20-20 of the European Union, energy consumption is reduced by $20 \%$, renewable resources have a share in power generation of over $20 \%$ and $\mathrm{CO}_{2}$ emissions are reduced almost by $20 \%$.

The net result is minimal social and economic impact in Western Greek Macedonia, stable power grid, large energy independence from imported energy sources such as natural gas and huge annual financial savings for Public Power Corporation of Greece S.A. in the order of 3 billion $€$.

\section{Acknowledgments}

Authors would like to thank Dr. Andy Mort, geochemist, of the Geological Survey of CanadaCalgary for editing this paper.

\section{References}

European Union, 2012. Available online at:

http://ec.europa.eu/energy/observatory/countries/countries_en.htm

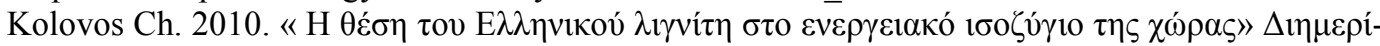

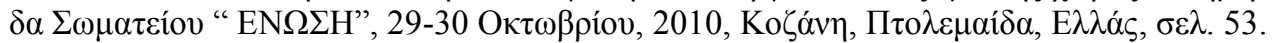

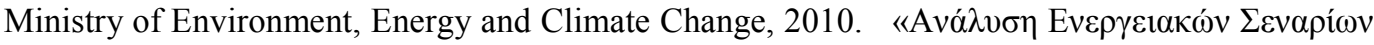

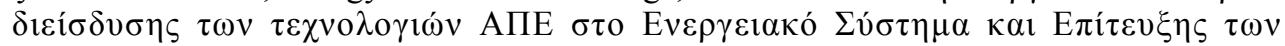

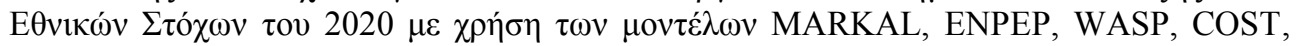

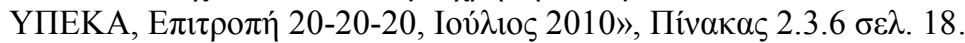

National Natural Gas System Operator (DESFA) S.A, December 2012. Tariff Regulation of the Basic Activities of the National Natural Gas System, Available online at: http://www.desfa.gr/default.asp?pid=535\&la=2

Operator of Electricity Market December, 2012. Available online at: http://www.lagie.gr/systima-eggyimenon-timon/ape-sithya/adeiodotiki-diadikasiakodikopoiisi-nomothesias-ape/periechomena/times-energeias-apo-ape-sithya-plin-fb/

Operator of Electricity Market S.A., December, 2012. Available online at: http://www.lagie.gr/systima-eggyimenon-timon/ape-sithya/adeiodotiki-diadikasiakodikopoiisi-nomothesias-ape/periechomena/times-energeias-apo-ape-sithya-plinfb/times-energeias-apo-fb-ektos-eidikon-programmaton/

Papanicolaou, C., 2001. Atlas of Greek coals. Coal petrographic parameters. Quality-Biomarkers (in Greek), Institute of Geology and Minelal Exploration, Athens, Greece 418 p. ISBN 96087453-1-4

Public Power Corporation, 2012. Available online at: www.dei.gr

Public Power Corporation of Greece S.A. Division of Mines, 2011. 


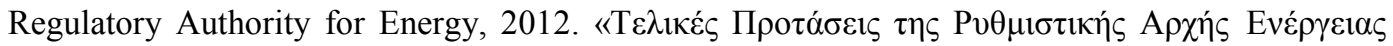

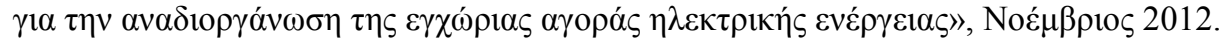

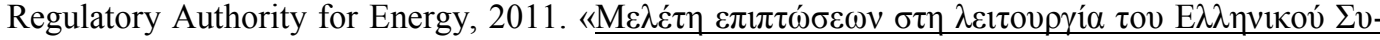

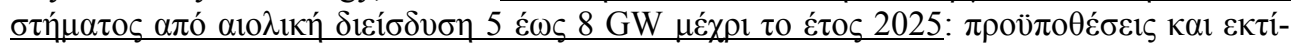

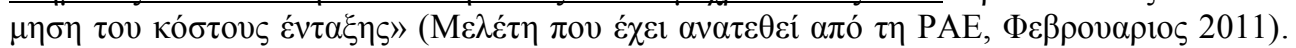
Available online at:

http://www.rae.gr/site/categories_new/renewable_power/ape_penetration.csp

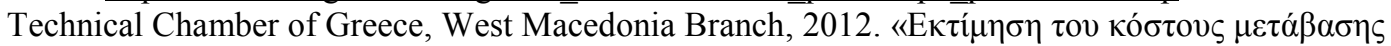

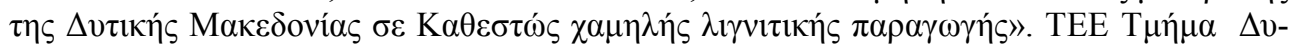

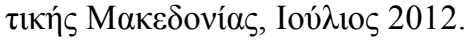

United Nations Framework Convention on Climate Change, 2012. Available online at:

http://unfccc.int/national reports/annex i ghg inventories/national inventories submissio ns/items/6598.php 